\title{
SODIUM RESTRICTION AND CATION EXCHANGE RESIN THERAPY IN NEPHROTIC CHILDREN
}

\author{
By F. M. MATEER, LORAINE H. ERHARD, MARJORIE PRICE, F. A. WEIGAND, \\ J. H. PETERS, T. S. DANOWSKI, R. TARAIL, AND L. GREENMAN \\ (From the Department of Research Medicine, the Renzichausen Foundation, and the Children's \\ and Presbyterian Hospitals of the University of Pittsburgh School of Medicine, \\ Pittsburgh, Pa.)
}

(Submitted for publication April 23, 1951; accepted July 9, 1951)

Programs of prevention or therapy of edema in nephrotic children in use at present still fail to resolve a number of problems. Thus the efficacy of repeated plasma or serum albumin infusions carries with it dangers of reactions as well as certain economic burdens (1-3). Plasma substitutes such as gelatin, polymerized glucose ("Dextran"), or polyvinyl pyrrolidone ("Periston"), have not received sufficiently prolonged clinical trials to exclude the possibility of sequellae such as those which follow acacia therapy (4-7). Similarly, certain practical obstacles attend the application of instruments available for vivodialysis, even when they function efficiently in reducing extracellular volume. Alternative approaches to the therapy of edema such as the infusion of sodium and potassium salts, the use of osmotic diuretics, the injection of nitrogen mustard, the administration of cortisone or of ACTH or the exposure to febrile infections, particularly rubeola, have been only sporadically successful (8-16). Finally, even though complete elimination of sodium from the intake may control edema, such rigid dietary restriction is not acceptable to many patients. It has therefore seemed desirable to us to try one member of a group of agents, the cation exchangers, recently made available for clinical testing. These polymers, ingested by mouth in an appropriate cycle, increase the stool excretion of sodium and of potassium (17-19). The studies which were conducted have provided answers to the following questions: $a$ ) is the medication sufficiently acceptable to permit prolonged therapy, $b$ ) how effective is it in abstracting cations from the diet and from body fluids, $c$ ) does it enhance the loss of edema which can be achieved by sodium restriction alone, and $d$ ) does its administration entail undue hazards to the patient?

\section{MATERIALS AND METHODS}

A carboxylic cation exchange resin in the hydrogen cycle was administered during a total of $\mathbf{1 5}$ periods three to six days long to four edematous nephrotic children. With few exceptions sodium intake was markedly restricted, i.e., to 1 to $3 \mathrm{meq}$./day prior to, during and after resin administration. The diet consisted of a lowsodium milk ("Lonalac") with added milk protein ("Protinal") and carbohydrate (beta-lactose) and contained adequate amounts of calories and nitrogen as well as considerable amounts of chloride and potassium. 1 The patients received in addition, 0.6 to $0.9 \mathrm{~g}$. of ferrous sulphate and maintenance vitamins each day. Water was allowed as desired. Changes during and following resin therapy have been compared with those observed in the same subjects during control periods on sodium restriction alone. Balance procedure, analytical techniques and methods of calculation have been described earlier (20-23). Findings are expressed when possible in statistical terms. Protocols are presented in the appendix.

\section{RESULTS}

Attempts to maintain the daily intake of the resin at 30 to $40 \mathrm{~g}$., amounts readily taken by essentially healthy children in control studies (20), were only partially successful. As a result the mean daily intake proved to be only $17.7 \pm$ S.D. $12.4 \mathrm{~g}$. Despite this relatively low dosage certain clearly evident changes appeared in these subjects as a group. These are reviewed and then the stool findings are compared with those following replacement of the low-sodium regimen by a full diet.

\section{A. Resin effects during the essentially sodium-free regimen}

From the original data in Table I and the statistical summary in Figure 1 it is evident that with

1 Composition of formula: "Lonalac" $125 \mathrm{~g}$.; "Protinal" $30 \mathrm{~g}$.; $\beta$-lactose $25 \mathrm{~g}$.; sucrose $15 \mathrm{~g}$.; diluted to $1000 \mathrm{ml}$. with water. Final concentration of sodium 1.1 meq./1.; potassium 44.9 meq./1.; chloride 18.5 meq./1.; nitrogen $8.2 \mathrm{~g} . / 1$. 
resin ingestion the serum carbon dioxide content decreased on the average 4.10 meq./1. (9.10 vol. $\%$ ) below control values and returned to previous levels following cessation of therapy. This was not accompanied by a rise in mean serum chloride of the type observed with the acidifying cation exchangers in previous animal and human studies (20-21), even though in the post resin period a statistically significant drop in the opposite direction did occur. The only other measured serum constituent to show change was potassium. The average levels diminished by almost 1 meq. during therapy and subsequently returned to pretreatment values.

Stool potassium excretion (Figure 2 and Table II) rose during resin ingestion above rates characteristic of the control and post resin periods in these patients, irrespective of whether it is expressed in terms of milliequivalents per day, milliequivalents per $100 \mathrm{~g}$. of stool or milliequivalents per gram of nitrogen. At the same time urinary excretion of this cation fell off significantly (Figure 2, based on urine data in Table II). The fact that the external balance of potassium did not vary discernibly during those alterations supports the view that these stool and urine potassium changes tended to cancel one another. The lower urinary excretion of potassium persisted into the post resin periods (Figure 2).

Insofar as sodium is concerned, keeping in mind that these patients were on an intake markedly restricted as to sodium content, there is no consistent evidence that stool sodium rose significantly; only the excretion per $100 \mathrm{~g}$. of stool nitro-

TABLE I

Body weight and analyses of blood and serum in nephrotic children receiving the $H$ cycle resin

\begin{tabular}{|c|c|c|c|c|c|c|c|c|c|c|c|c|c|}
\hline \multirow{2}{*}{$\frac{\text { Subject }}{\text { (Ace-sex) }}$} & \multirow{2}{*}{$\frac{\text { Ine }}{\text { (dnys) }}$} & \multirow{2}{*}{$\frac{\text { Therapy }}{(\mathrm{g} \cdot / \mathrm{d} \text { ) }}$} & \multirow{2}{*}{$\frac{\text { Body wet. }}{\left(x_{\bullet}\right)}$} & \multicolumn{2}{|c|}{ Blood } & \multicolumn{8}{|c|}{ Serun } \\
\hline & & & & \begin{tabular}{|l|} 
Sugar \\
(agin $\%)$
\end{tabular} & $\begin{array}{c}\text { NPN } \\
(\text { (n) }\end{array}$ & 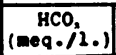 & $\begin{array}{c}C l \\
(\operatorname{meq} \cdot / 1 .)\end{array}$ & $\mathrm{Ma}_{(\mathbf{m} q . / 1 .)}$ & $\begin{array}{c}\mathrm{X} \\
(\operatorname{meq} \cdot / 1,)^{\prime}\end{array}$ & $\underset{(n g a n d,}{\mathrm{Ca}}$ & $\underset{(m g a x)}{P}$ & $\begin{array}{c}\mathrm{H}_{2} 0 \\
(\mathrm{~B} \cdot / 1 .)\end{array}$ & \begin{tabular}{|c|} 
Protein \\
$(8 . \%)$
\end{tabular} \\
\hline${ }_{6}^{8 P} n$ & $\begin{array}{r}0 \\
0-3 \\
3-6 \\
6-9 \\
9-12 \\
12-15 \\
15-18 \\
18-21 \\
21-24 \\
50 \\
50-56 \\
56-58\end{array}$ & $\begin{array}{r}0 \\
0 \\
0 \\
0 \\
0 \\
33 \\
18 \\
0 \\
0 \\
0 \\
17 \\
14 \\
\end{array}$ & $\begin{array}{l}22.6 \\
23.0 \\
19.8 \\
18.9 \\
18.4 \\
17.0 \\
16.8 \\
17.0 \\
17.2 \\
. \\
- \\
-\end{array}$ & $\begin{array}{l}- \\
- \\
- \\
- \\
- \\
- \\
- \\
- \\
-\end{array}$ & $\begin{array}{l}92 \\
30 \\
25 \\
29 \\
32 \\
36 \\
37 \\
32 \\
33 \\
39 \\
36 \\
29 \\
\end{array}$ & $\begin{array}{l}23.1 \\
22.9 \\
23.6 \\
23.1 \\
22.5 \\
14.9 \\
17.1 \\
23.7 \\
24.0 \\
21.4 \\
16.9 \\
14.7\end{array}$ & $\begin{array}{r}105.1 \\
105.3 \\
105.1 \\
105.1 \\
104.1 \\
106.0 \\
102.6 \\
99.0 \\
97.8 \\
103.0 \\
114.2 \\
114.3 \\
\end{array}$ & $\begin{array}{l}139 \\
138 \\
139 \\
130 \\
134 \\
133 \\
133 \\
137 \\
133 \\
133 \\
133 \\
135 \\
\end{array}$ & $\begin{array}{l}5.3 \\
4.6 \\
4.5 \\
4.6 \\
5.2 \\
4.8 \\
3.3 \\
3.8 \\
5.4 \\
5.1 \\
3.6 \\
3.2\end{array}$ & $\begin{array}{c}8.1 \\
- \\
8.0 \\
8.4 \\
- \\
8.3 \\
8.2 \\
9.2 \\
- \\
-\end{array}$ & $\begin{array}{c}5.4 \\
- \\
5.0 \\
5.7 \\
= \\
6.2 \\
= \\
= \\
= \\
\end{array}$ & $\begin{array}{l}929 \\
933 \\
937 \\
934 \\
- \\
925 \\
928 \\
931 \\
- \\
926 \\
936 \\
937 \\
\end{array}$ & $\begin{array}{l}A: 0 \\
0.8: 3 \cdot 3 \\
0.8: 3.8 \\
0.7: 40 \\
0.7: 40 \\
0.7: 4.0 \\
0.3: 4.2 \\
0.6: 40\end{array}$ \\
\hline$\underset{3 t}{m}=$ & $\begin{array}{r}0 \\
0-6 \\
6-12 \\
12-19 \\
19-22 \\
22-25 \\
\end{array}$ & $\begin{array}{r}0 \\
0 \\
10 \\
1 \\
2 \\
0 \\
\end{array}$ & $\begin{array}{l}16.6 \\
16.4 \\
15.8 \\
15.8 \\
16.0 \\
15.8 \\
\end{array}$ & $\begin{array}{l}90 \\
90 \\
94 \\
90 \\
13\end{array}$ & $\begin{array}{l}40 \\
35 \\
36 \\
34 \\
45 \\
46 \\
\end{array}$ & $\begin{array}{l}16.7 \\
18.4 \\
20.3 \\
18.7 \\
18.3 \\
20.4 \\
\end{array}$ & $\begin{array}{l}102.3 \\
105.7 \\
109.4 \\
108.4 \\
105.9 \\
106.5\end{array}$ & $\begin{array}{l}131 \\
134 \\
136 \\
137 \\
145 \\
140 \\
\end{array}$ & $\begin{array}{l}5.8 \\
5.9 \\
4.9 \\
3.7 \\
5.1 \\
5.4\end{array}$ & $\begin{array}{l}7.9 \\
7.7 \\
7.6 \\
6.5 \\
6.6 \\
\end{array}$ & $\begin{array}{l}-5.0 \\
5.6 \\
5.5 \\
6.8 \\
5.2 \\
\end{array}$ & $\begin{array}{l}940 \\
951 \\
950 \\
938 \\
942\end{array}$ & $\begin{array}{l}0.2: 3.2 \\
0.4: 2.9 \\
0.1: 32\end{array}$ \\
\hline${ }_{6}{ }^{n}$ & $\begin{array}{r}0 \\
0-7 \\
8 \\
-14\end{array}$ & $\begin{array}{l}0 \\
9 \\
0 \\
0 \\
\end{array}$ & $\begin{array}{c}16.8 \\
16.3 \\
14.2 \\
- \\
\end{array}$ & $\begin{array}{l}73 \\
- \\
78 \\
84 \\
\end{array}$ & $\begin{array}{l}86 \\
6 \\
68 \\
68 \\
\end{array}$ & $\begin{array}{r}13.2 \\
3.3 \\
7.6 \\
10.0 \\
\end{array}$ & $\begin{array}{l}113.8 \\
110.1 \\
110.2 \\
102.5 \\
\end{array}$ & $\begin{array}{l}136 \\
135 \\
142 \\
123 \\
\end{array}$ & $\begin{array}{l}4.1 \\
3.1 \\
2.5 \\
2.6 \\
\end{array}$ & $\begin{array}{l}7.2 \\
7.1 \\
6.7 \\
5.5\end{array}$ & $\begin{array}{l}4.3 \\
3.0 \\
3.2 \\
3.6 \\
\end{array}$ & $\begin{array}{c}908 \\
- \\
908 \\
903\end{array}$ & $\begin{array}{l}0.6: 2.6 \\
0.8: 3.2 \\
0.8: 3.6\end{array}$ \\
\hline $\begin{array}{l}\text { DI } \\
12 n\end{array}$ & $\begin{array}{r}0 \\
0-7 \\
7-10 \\
10-13 \\
13-17 \\
17-19 \\
19-22 \\
20-25 \\
25-28 \\
28-31 \\
31-33 \\
33-36 \\
36-39 \\
65 \\
65-70 \\
70-76 \\
110 \\
10-117 \\
10-121\end{array}$ & $\begin{array}{r}0 \\
0 \\
14 \\
14 \\
0 \\
0 \\
0 \\
0 \\
0 \\
21 \\
0 \\
0 \\
0 \\
0 \\
33 \\
0 \\
0 \\
17 \\
0\end{array}$ & $\begin{array}{l}30.2 \\
29.8 \\
29.4 \\
29.2 \\
29.2 \\
29.0 \\
28.4 \\
29.4 \\
29.3 \\
29.8 \\
30.2 \\
30.2 \\
29.2 \\
30.2 \\
29.2 \\
30.2 \\
31.4 \\
30.8 \\
28.4 \\
\end{array}$ & $\begin{array}{l}85 \\
- \\
- \\
- \\
- \\
- \\
- \\
- \\
- \\
8 \\
- \\
9 \\
- \\
-\end{array}$ & $\begin{array}{l}31 \\
32 \\
- \\
31 \\
31 \\
30 \\
45 \\
29 \\
28 \\
36 \\
38 \\
35 \\
31 \\
39 \\
35 \\
34 \\
40 \\
48 \\
47 \\
\end{array}$ & $\begin{array}{l}19.8 \\
19.7 \\
20.1 \\
20.9 \\
25.0 \\
26.3 \\
26.8 \\
24.4 \\
22.7 \\
17.9 \\
18.9 \\
20.8 \\
22.5 \\
19.9 \\
14.0 \\
20.6 \\
16.2 \\
19.8\end{array}$ & $\begin{array}{l}106.9 \\
110.8 \\
111.0 \\
108.8 \\
101.6 \\
106.5 \\
104.4 \\
100.6 \\
104.3 \\
110.8 \\
101.0 \\
110.4 \\
109.9 \\
107.4 \\
115.5 \\
113.6 \\
109.7 \\
106.7 \\
104.1\end{array}$ & $\begin{array}{l}142 \\
138 \\
133 \\
134 \\
137 \\
147 \\
138 \\
134 \\
137 \\
139 \\
138 \\
137 \\
139 \\
136 \\
133 \\
148 \\
144 \\
143 \\
145\end{array}$ & $\begin{array}{l}4.4 \\
4.7 \\
5.1 \\
4.2 \\
4.1 \\
4.3 \\
4.3 \\
4.6 \\
4.0 \\
4.2 \\
3.8 \\
3.7 \\
4.3 \\
3.9 \\
3.1 \\
3.5 \\
5.1 \\
3.5 \\
3.2\end{array}$ & $\begin{array}{c}-1.6 \\
- \\
7.0 \\
- \\
7.1 \\
- \\
7.7 \\
7.6 \\
- \\
7.2 \\
0.1 \\
\div \\
7.9 \\
7.4 \\
6.4 \\
7.2\end{array}$ & $\begin{array}{c}5.3 \\
6.1 \\
0 \\
4.4 \\
4.4 \\
\vdots .1 \\
4.5 \\
5.2 \\
0 \\
4.3 \\
4.5 \\
4.4 \\
4.3 \\
6.9 \\
3.4\end{array}$ & $\begin{array}{c}931 \\
929 \\
-16 \\
916 \\
913 \\
923 \\
916 \\
920 \\
- \\
927 \\
935 \\
- \\
929 \\
929 \\
923 \\
- \\
930 \\
- \\
926\end{array}$ & $\begin{array}{l}0.3: 3.6 \\
0.2: 4.2 \\
0.6: 3.5 \\
0.2: 4.2 \\
0.5: 3.7 \\
0.3: 3.5 \\
0.2: 3.6 \\
0.4: 3.8 \\
0.4: 3.5 \\
0.6: 4.2 \\
0.4: 3.4 \\
0.7: 2.4 \\
0.5: 3.5\end{array}$ \\
\hline
\end{tabular}


gen increased without change in the other two categories. Even this isolated change, however, is of too small magnitude to represent any substantial influence of the exchanger on stool sodium. Neither did the urinary excretion of this electrolyte fall off significantly, though the mean values proved to be somewhat lower. These essentially negative findings are further supported by the observations that the fluctuations in the external and internal balances of sodium did not show, as will be seen later, any real trend which could be attributed to resin.

The small change in the daily stool chloride excretion in the per day and per gram of nitrogen categories, and the lowered urinary output of this ion during resin therapy remain unexplained (Figure 2). These stool chloride changes may merely reflect the limited number of control observations available prior to therapy, but comparison of them with a much larger group of samples obtained in control studies in subjects on an identical regimen (20) reveals the same difference. Whatever the reason may be, the stool changes are of too small magnitude to have any influence on the daily transfers of this anion or of nitrogen. On the other hand, insofar as the lowered urinary chloride values are concerned, it is conceivable that they appeared secondary to decreased potassium excretion. Against this is the finding that in the post resin periods still characterized by the lowered potassium excretion such a relationship cannot be postulated. It is more likely that renal retention of chloride is related to acidosis (21).

Perusal of the summarized mean balance values during the pre and post resin periods (Figure 3 ) clearly indicates that a low-sodium regimen of the type herein described may by itself induce negative external balances of sodium and of chloride with a

$$
\begin{array}{llll}
\Delta \mathrm{HCO}_{3} & \Delta \mathrm{Cl} & \Delta \mathrm{Na} & \Delta \mathrm{K}
\end{array}
$$

meq/1

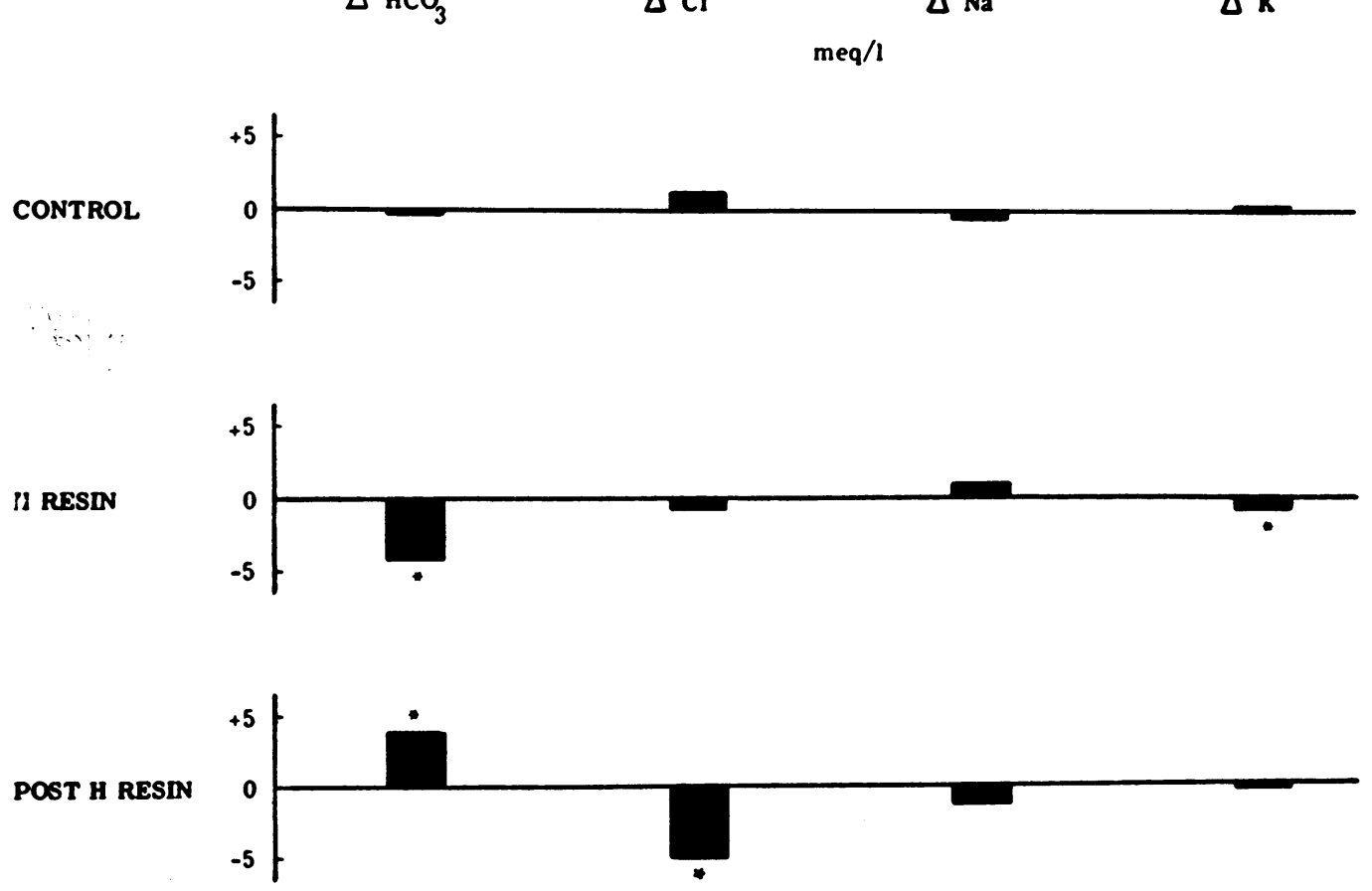

Fig. 1. Mean Changes in Serum Concentration Before, During and After Resin Therapy

Fluctuations in serum constituents $\left(\triangle \mathrm{HCO}_{3}, \mathrm{Cl}, \mathrm{Na}\right.$, and $\left.\mathrm{K}\right)$ during and following $\mathrm{H}$ form resin ingestion have been compared statistically and graphically with those recorded prior to therapy. Asterisks identify mean values found to have a " $p$ " for the " $t$ " test of less than 0.05 , and indicate therefore a statistically significant difference. Resin administration reduced the serum bicarbonate content with subsequent restitution during the post $\mathrm{H}$ resin periods. The chloride did not change significantly until the resin had been withdrawn at which time a significant decline was observed. The only other change of note was the decrease of 0.93 meq./1. in the mean serum potassium concentrations (S.E. \pm 0.31 ). 
decrease in extracellular volume, diuresis, and a loss of body weight. Furthermore, the rates of extracellular sodium and water loss, and of fall in body weight characteristic of the control periods on low-sodium therapy only, were not visibly accelerated by these amounts of resin. Strength is added to these interpretations by noting that the patients were in positive nitrogen balance during the control and resin periods and hence the losses in body weight cannot be attributed to inadequate intake. In the post resin period the nephrotic children took insufficient amounts of milk and developed negative external and cell balances of nitrogen (Table III and Figure 3).

\section{B. Effects associated with resin intake during an unrestricted diet}

During days 50 to 58 in $\mathrm{BF}$ and 65 to 76 in DY, the low-sodium regimen was replaced during continued resin ingestion by a full diet containing ordinary amounts of sodium (Table II). Though complete balance data are not available and the observations are limited to three in number it should be pointed out that in each instance the patients ate well and took larger amounts of resin. The daily stool sodium and potassium output exceeded by a wide margin values observed in a large series of control subjects on comparable diets without resin (20), and unquestionably exceeded greatly the stool sodium values seen in these same patients while on resin and a low-sodium diet. Chloride and nitrogen output, on the other hand, were not unusual. It is clear, therefore, that in these subjects, as in others (21), the resin can increase stool losses of sodium and, of course, of potassium as well during periods in which sodium is present in the diet.

\section{General comments and clinical course}

All four of the patients continued to deliver their edema with only occasional interruptions irrespective of whether or not they were receiving the cation exchanger.

The nonprotein nitrogen of the blood returned to normal in BF, fluctuated between elevated and non-elevated concentrations in KM, remained high in DW, and rose to azotemic levels in DY (Table I). The patient with the most pronounced reduction of serum carbon dioxide content (DW) de-

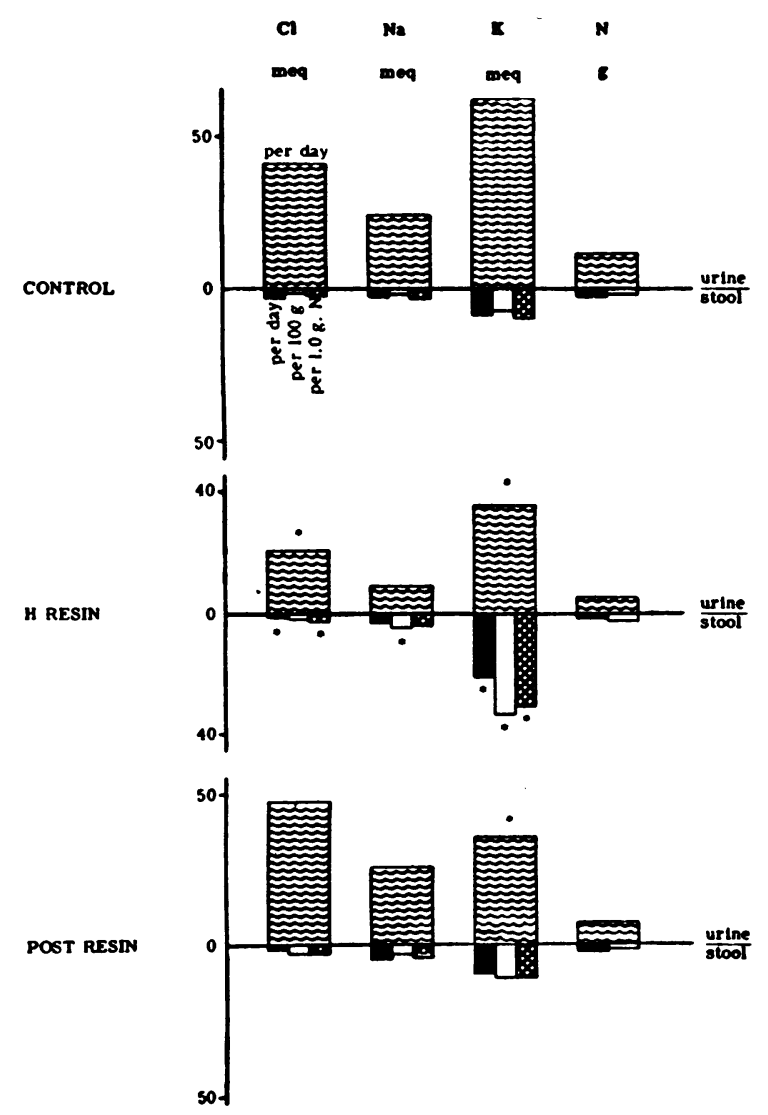

Fig. 2. Electrolyte and Nitrogen Excretion in Urine and in Feces Before, During, and After Resin THERAPY

Statistically significant increases or decreases from control mean values are marked by an asterisk. It is readily evident that as stool potassium increased, the urinary output of this electrolyte declined. The lowered output of potassium in urine persisted during the post resin period. Changes in stool chloride and in stool sodium were limited to one or two of the categories in contrast to the uniformity of the stool potassium data. Urinary chloride excretion was low during the resin ingestion periods.

veloped over-breathing on the seventh day of hydrogen form resin therapy coincidental with a respiratory infection, even though he had taken only $9 \mathrm{~g}$. each day. This responded promptly to therapy with parenteral sodium bicarbonate preceded by calcium gluconate and antibiotics. Despite the hypocalcemia present in this child and in the others none of the patients developed tetany during resin therapy. This fact, together with the slight elevations, if any, in serum phosphorus indicate that the low serum calcium values were pri- 
TABLE II

Intake data and urine and stool output in nephrotic children receiving the $H$ cycle resin

\begin{tabular}{|c|c|c|c|c|c|c|c|c|c|c|c|c|c|c|c|c|c|c|}
\hline ubs. & Tim & Sherepy & & & Intake & & & & & Urd & & & & & & Stool & & \\
\hline & (dars) & $(\mathrm{s} . / \mathrm{d})$. & $\begin{array}{c}\text { Thusd } \\
(1 .)\end{array}$ & $\begin{array}{c}\text { Cl } \\
\text { (meg.) }\end{array}$ & $\begin{array}{c}M_{a} \\
(m e q .)\end{array}$ & \begin{tabular}{|c|}
$x$ \\
$($ mog. \\
\end{tabular} & (am.) & $\begin{array}{l}\text { vol. } \\
\text { (1.) }\end{array}$ & $\begin{array}{c}c 1 \\
\text { (meq.) }\end{array}$ & $\begin{array}{c}\mathrm{Ma} \\
\left(\operatorname{mog}_{0}\right)\end{array}$ & $\begin{array}{c}x \\
(1009 . \\
\end{array}$ & $\begin{array}{c}5 x \\
\left(g^{n} .\right) \\
\end{array}$ & 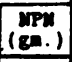 & $\begin{array}{l}\text { Mete; } \\
\text { (ean; }\end{array}$ & $\begin{array}{c}\text { C1 } \\
(000 .)\end{array}$ & $\begin{array}{c}m a \\
(n 00 .)\end{array}$ & 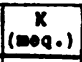 & $(\mathbf{x})$ \\
\hline$B$ & $\begin{array}{r}0-3 \\
3-6 \\
6-9 \\
9-12 \\
12-15 \\
15-18 \\
18-21 \\
21-24 \\
50-56 \\
56-58 \\
\end{array}$ & $\begin{array}{r}0 \\
0 \\
0 \\
0 \\
33 \\
18 \\
0 \\
0 \\
17 \\
14 \\
\end{array}$ & $\begin{array}{l}6.25 \\
5.41 \\
5.47 \\
5.31 \\
6.82 \\
5.85 \\
5.97 \\
7.07 \\
\text { roll }\end{array}$ & $\begin{array}{r}94 \\
90 \\
94 \\
90 \\
94 \\
63 \\
94 \\
94 \\
\text { det }\end{array}$ & $\begin{array}{l}6 \\
5 \\
6 \\
5 \\
6 \\
4 \\
6 \\
6\end{array}$ & $\begin{array}{l}229 \\
220 \\
229 \\
220 \\
229 \\
153 \\
229 \\
229\end{array}$ & $\begin{array}{l}27.0 \\
25.9 \\
27.0 \\
25.9 \\
27.0 \\
18.0 \\
27.0 \\
27.0\end{array}$ & $\begin{array}{l}3.48 \\
3.71 \\
2.75 \\
2.88 \\
3.65 \\
3.72 \\
4.05 \\
5.52 \\
3.80 \\
1.03 \\
\end{array}$ & $\begin{array}{r}109 \\
249 \\
189 \\
144 \\
69 \\
42 \\
73 \\
86 \\
50 \\
38 \\
\end{array}$ & $\begin{array}{r}9 \\
212 \\
176 \\
63 \\
0 \\
0 \\
0 \\
23 \\
7 \\
3 \\
\end{array}$ & $\begin{array}{r}173 \\
163 \\
88 \\
176 \\
98 \\
12 \\
64 \\
216 \\
68 \\
18 \\
\end{array}$ & $\begin{array}{r}20.1 \\
14.6 \\
7.6 \\
18.9 \\
14.9 \\
16.9 \\
18.6 \\
23.8 \\
23.1 \\
9.4\end{array}$ & $\begin{array}{r}16.4 \\
13.1 \\
7.0 \\
17.4 \\
13.5 \\
14.7 \\
15.6 \\
20.9 \\
20.2 \\
7.9 \\
\end{array}$ & 499 & $\begin{array}{r}- \\
13 \\
5 \\
6 \\
2\end{array}$ & $\begin{array}{r}17 \\
5 \\
34 \\
3 \\
68\end{array}$ & $\begin{array}{r}52 \\
71 \\
241 \\
104 \\
112\end{array}$ & $\begin{array}{l}4.2 \\
5.2 \\
5.2 \\
9.8 \\
2.8\end{array}$ \\
\hline Da & $\begin{array}{r}0-6 \\
6-12 \\
12-19 \\
19-22 \\
22-25\end{array}$ & $\begin{array}{r}0 \\
10 \\
1 \\
2 \\
0 \\
\end{array}$ & $\begin{array}{l}8.36 \\
7.21 \\
6.94 \\
4.21 \\
3.84 \\
\end{array}$ & $\begin{array}{r}190 \\
178 \\
151 \\
100 \\
85 \\
\end{array}$ & $\begin{array}{r}21 \\
10 \\
9 \\
6 \\
5 \\
\end{array}$ & $\begin{array}{l}451 \\
423 \\
358 \\
238 \\
201 \\
\end{array}$ & $\begin{array}{r}54.2 \\
50.9 \\
43.1 \\
28.6 \\
-\quad \\
\end{array}$ & $\begin{array}{l}1.84 \\
1.95 \\
0.95 \\
1.75 \\
\end{array}$ & $\begin{array}{r}98 \\
911 \\
54 \\
46 \\
\end{array}$ & $\begin{array}{l}- \\
7 \\
9 \\
3 \\
0 \\
\end{array}$ & $\begin{array}{r}- \\
103 \\
156 \\
71 \\
74 \\
\end{array}$ & $\begin{array}{l}29.1 \\
36.8 \\
17.2 \\
33.8 \\
\end{array}$ & $\begin{array}{l}24.9 \\
33.9 \\
15.8 \\
33.5 \\
\end{array}$ & 746 & $\begin{array}{r}19 \\
15 \\
1 \\
\end{array}$ & $\begin{array}{r}12 \\
14 \\
5 \\
\end{array}$ & $\begin{array}{r}47 \\
343 \\
26 \\
\end{array}$ & $\begin{array}{l}7.9 \\
7.8 \\
1.6 \\
\end{array}$ \\
\hline DW & $\begin{array}{r}0-7 \\
7-26\end{array}$ & $\begin{array}{l}9 \\
0 \\
\end{array}$ & $\begin{array}{l}8.99 \\
\text { Puil } \\
\end{array}$ & & $\begin{array}{c}6 \\
\text { centt }\end{array}$ & $\begin{array}{c}244 \\
\text { eroete }\end{array}$ & 28.8 & $\begin{array}{l}5.58 \\
5.60 \\
\end{array}$ & $\begin{array}{l}225 \\
227 \\
\end{array}$ & $\begin{array}{r}79 \\
286 \\
\end{array}$ & $\begin{array}{r}198 \\
67 \\
\end{array}$ & $\begin{array}{l}21.3 \\
25.5 \\
\end{array}$ & $\begin{array}{l}17.0 \\
10.9 \\
\end{array}$ & $\begin{array}{r}107 \\
80 \\
\end{array}$ & $\begin{array}{l}0.4 \\
3\end{array}$ & $\begin{array}{l}5 \\
3 \\
\end{array}$ & $\begin{array}{l}48 \\
21 \\
\end{array}$ & $\begin{array}{l}1.2 \\
0.2 \\
\end{array}$ \\
\hline Dr & $\begin{array}{r}0-7 \\
7-10 \\
10-13 \\
13-17 \\
17-19 \\
19-22 \\
22-25 \\
25-28 \\
26-31 \\
31-33 \\
33-36 \\
36-39 \\
65-70 \\
70-76 \\
10-117 \\
17-122\end{array}$ & $\begin{array}{r}0 \\
14 \\
24 \\
0 \\
0 \\
0 \\
0 \\
0 \\
21 \\
0 \\
0 \\
0 \\
33 \\
40 \\
17 \\
0\end{array}$ & $\begin{array}{r}24.26 \\
8.35 \\
8.25 \\
7.25 \\
3.31 \\
6.04 \\
9.11 \\
6.16 \\
6.52 \\
3.23 \\
6.48 \\
5.08 \\
7011 \\
11 \\
24.32 \\
8.20\end{array}$ & 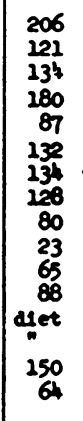 & $\begin{array}{r}12 \\
6 \\
6 \\
7 \\
4 \\
6 \\
6 \\
5 \\
5 \\
1 \\
4 \\
5\end{array}$ & $\begin{array}{c}500 \\
256 \\
269 \\
359 \\
173 \\
264 \\
267 \\
253 \\
188 \\
56 \\
157 \\
212 \\
\\
363 \\
156\end{array}$ & $\begin{array}{r}59.0 \\
25.5 \\
25.5 \\
36.0 \\
17.3 \\
208.2 \\
208.9 \\
216.2 \\
33.6 \\
10.3 \\
28.7 \\
39.0 \\
\\
66.7 \\
28.6\end{array}$ & \begin{tabular}{|r|}
9.20 \\
6.62 \\
7.25 \\
5.35 \\
1.95 \\
6.20 \\
3.60 \\
3.60 \\
5.30 \\
3.30 \\
4.39 \\
5.20 \\
14.45 \\
10.98 \\
10.80 \\
8.10 \\
\end{tabular} & \begin{tabular}{|r}
239 \\
187 \\
249 \\
271 \\
72 \\
248 \\
108 \\
75 \\
64 \\
68 \\
170 \\
339 \\
1012 \\
971 \\
268 \\
427
\end{tabular} & $\begin{array}{r}0 \\
62 \\
93 \\
52 \\
12 \\
22 \\
11 \\
9 \\
15 \\
0 \\
99 \\
246 \\
636 \\
720 \\
175 \\
363\end{array}$ & $\begin{array}{l}443 \\
212 \\
202 \\
289 \\
105 \\
243 \\
213 \\
179 \\
189 \\
122 \\
157 \\
206 \\
301 \\
191 \\
284 \\
198\end{array}$ & \begin{tabular}{|r|}
49.4 \\
19.6 \\
24.6 \\
34.6 \\
21.7 \\
66.8 \\
106.9 \\
75.2 \\
30.8 \\
22.1 \\
23.8 \\
34.8 \\
59.8 \\
62.4 \\
66.9 \\
42.8
\end{tabular} & \begin{tabular}{|l|}
37.5 \\
18.5 \\
18.8 \\
27.5 \\
9.1 \\
61.6 \\
83.3 \\
57.6 \\
24.4 \\
17.4 \\
18.8 \\
28.2 \\
47.7 \\
54.6 \\
58.0 \\
33.8
\end{tabular} & \begin{tabular}{|r}
-1049 \\
384 \\
-1063 \\
1444 \\
1179 \\
804 \\
677
\end{tabular} & $\begin{array}{r}11 \\
21 \\
6 \\
1 \\
0 \\
17 \\
5 \\
8 \\
5 \\
1\end{array}$ & $\begin{array}{r}10 \\
10 \\
4 \\
9 \\
21 \\
78 \\
347 \\
148 \\
47 \\
23\end{array}$ & $\begin{array}{r}44 \\
82 \\
99 \\
65 \\
146 \\
52 \\
173 \\
176 \\
214 \\
13\end{array}$ & $\begin{array}{r}6.1 \\
5.9 \\
8.8 \\
9.0 \\
\\
5.3 \\
10.9 \\
7.6 \\
6.1 \\
9.8 \\
3.4\end{array}$ \\
\hline
\end{tabular}

TABLE III

External, extracellular, and cell balances in nephrotic children receiving the $H$ cycle resin

\begin{tabular}{|c|c|c|c|c|c|c|c|c|c|c|c|c|c|}
\hline \multirow[t]{2}{*}{ Subjoet } & \multirow{2}{*}{$\frac{9100}{\text { (dare) }}$} & \multirow{2}{*}{$\frac{\text { Thorapy }}{\text { (co/d.) }}$} & \multicolumn{4}{|c|}{ Ixt. Bel. } & \multicolumn{3}{|c|}{ Extracell. Bal. } & \multicolumn{3}{|c|}{ Cell Bal. } & \\
\hline & & & $\begin{array}{c}\text { Cl } \\
(=0.0)\end{array}$ & $\begin{array}{c}1 \times 0 \\
(\infty \times 0 .)\end{array}$ & $\begin{array}{c}x \\
(m 09 .) \\
\end{array}$ & $(x)$ & $\begin{array}{l}\text { म, } \\
\text { (2.) }\end{array}$ & $\begin{array}{c}M_{a} \\
(m e q .)\end{array}$ & $\begin{array}{c}x \\
(\operatorname{mog} .)\end{array}$ & $\begin{array}{r}N * \\
\left(g^{n} .\right) \\
\end{array}$ & $\begin{array}{c}M 0 \\
(m o g .)\end{array}$ & $\underset{(=09 .)}{x}$ & \\
\hline B & $\begin{array}{r}0-3 \\
3-6 \\
6-9 \\
9-12 \\
22-15 \\
15-18 \\
18-21 \\
21-24 \\
\end{array}$ & $\begin{array}{r}0 \\
0 \\
0 \\
0 \\
33 \\
18 \\
0 \\
0 \\
\end{array}$ & $\begin{array}{r}- \\
-102 \\
-62 \\
+21 \\
17 \\
17 \\
17 \\
13 \\
\end{array}$ & $\begin{array}{r}-16 \\
-217 \\
-174 \\
-63 \\
-612 \\
-15 \\
-15 \\
-21 \\
-21 \\
\end{array}$ & $\begin{array}{r}30 \\
+31 \\
+105 \\
+\quad 8 \\
+20 \\
+21 \\
+23 \\
+40 \\
\end{array}$ & $\begin{array}{r}+4.7 \\
+9.1 \\
+16.8 \\
+4.3 \\
+9.5 \\
-1.6 \\
+3.5 \\
1.8 \\
\end{array}$ & $\begin{array}{c}-0.1 \\
-1.3 \\
-0.9 \\
-0.5 \\
0 \\
+0.4 \\
+0.4 \\
+0.1 \\
\end{array}$ & $\begin{array}{r}-27 \\
-175 \\
-185 \\
-45 \\
0 \\
0 \\
+55 \\
+79 \\
-28 \\
\end{array}$ & $\begin{array}{r}-7 \\
-7 \\
-4 \\
+1 \\
-1 \\
-9 \\
+6 \\
+12 \\
\end{array}$ & $\begin{array}{r}+4.7 \\
+9.9 \\
+16.3 \\
+3.9 \\
+9.0 \\
+1.7 \\
+4.0 \\
+1.9 \\
\end{array}$ & $\begin{array}{r}+11 \\
-42 \\
+11 \\
=18 \\
-12 \\
=70 \\
-76 \\
-\quad 3 \\
\end{array}$ & $\begin{array}{r}+37 \\
+38 \\
+109 \\
+\quad 7 \\
+21 \\
+30 \\
+107 \\
-\quad 52 \\
\end{array}$ & $\div$ \\
\hline Dr & $\begin{array}{r}6-12 \\
12-19 \\
19-22 \\
22-25 \\
\end{array}$ & $\begin{array}{r}10 \\
1 \\
2 \\
0 \\
\end{array}$ & $\begin{array}{r}+77 \\
+32 \\
+42 \\
+\quad 37 \\
\end{array}$ & $\begin{array}{r}5 \\
: \quad 9 \\
\div \quad 3 \\
\end{array}$ & $\begin{array}{r}+192 \\
+\quad 52 \\
+103 \\
+200 \\
\end{array}$ & $\begin{array}{r}128.4 \\
+2.3 \\
+9.4 \\
\end{array}$ & $\begin{array}{l}+0.5 \\
+0.3 \\
+0.4 \\
+0.3 \\
\end{array}$ & $\begin{array}{r}54 \\
+\quad 67 \\
+132 \\
-\quad 6 \\
\end{array}$ & $\begin{array}{r}-5 \\
-7 \\
+12 \\
+4 \\
\end{array}$ & $\begin{array}{r}+18.4 \\
+2.3 \\
+9.4 \\
\end{array}$ & $\begin{array}{r}-59 \\
-76 \\
-135 \\
+\quad 4 \\
\end{array}$ & $\begin{array}{r}+197 \\
+59 \\
+91 \\
+96 \\
\end{array}$ & \\
\hline DN & $0-7$ & 2 & -26 & -80 & -2 & 16.2 & -0.2 & .27 & -4 & +8.6 & -63 & & \\
\hline Dr & $\begin{array}{r}0.7 \\
7-10 \\
10-13 \\
23-17 \\
17-29 \\
19-22 \\
22-25 \\
25-26 \\
26-31 \\
31-33 \\
33-36 \\
36-39 \\
210-217 \\
217-122\end{array}$ & $\begin{array}{r}0 \\
14 \\
14 \\
0 \\
0 \\
0 \\
0 \\
0 \\
21 \\
0 \\
0 \\
0 \\
17 \\
0\end{array}$ & 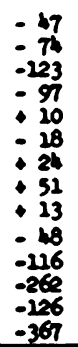 & $\begin{array}{l}=21 \\
=29 \\
=95 \\
=32 \\
=13 \\
=22 \\
=11 \\
=12 \\
=20 \\
=77 \\
=137 \\
=283 \\
-217 \\
-406\end{array}$ & 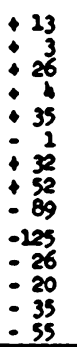 & $\begin{array}{r}3.3 \\
+2.7 \\
-2.2 \\
-4.8 \\
+2.4 \\
+38.2 \\
-1.2 \\
+35.4 \\
-0.4 \\
-214.0 \\
-0.8 \\
-12.2 \\
-10.2 \\
-17.8\end{array}$ & $\begin{array}{l}-0.7 \\
-0.7 \\
-0.9 \\
-0.4 \\
-0.1 \\
-0.1 \\
+0.5 \\
0.2 \\
-0.3 \\
-0.3 \\
-1.5 \\
-0.7 \\
-0.7 \\
-3.1\end{array}$ & $\begin{array}{l}-138 \\
-132 \\
-107 \\
-17 \\
+25 \\
-67 \\
+42 \\
+46 \\
-40 \\
-30 \\
+23 \\
-212 \\
-126 \\
-408\end{array}$ & $\begin{array}{r}-1 \\
0 \\
-10 \\
-2 \\
0 \\
0 \\
+4 \\
-4 \\
0 \\
-2 \\
-6 \\
-6 \\
-17 \\
-12\end{array}$ & $\begin{array}{r}+3.1 \\
+2.7 \\
-2.0 \\
-4.8 \\
+2.6 \\
+35.4 \\
+1.8 \\
+35.6 \\
-1.9 \\
-14.4 \\
-0.2 \\
-11.8 \\
-17.6\end{array}$ & 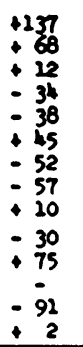 & $\begin{array}{r}+24 \\
+\quad 3 \\
+36 \\
+\quad 6 \\
+35 \\
+28 \\
+28 \\
+36 \\
-89 \\
-123 \\
-20 \\
-18 \\
-18 \\
-43\end{array}$ & 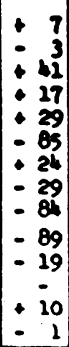 \\
\hline
\end{tabular}

* Corrected for balance of NPN ** Corrected for $\mathrm{K}$ associated with intracellular metabolism of $\mathrm{N}$ 

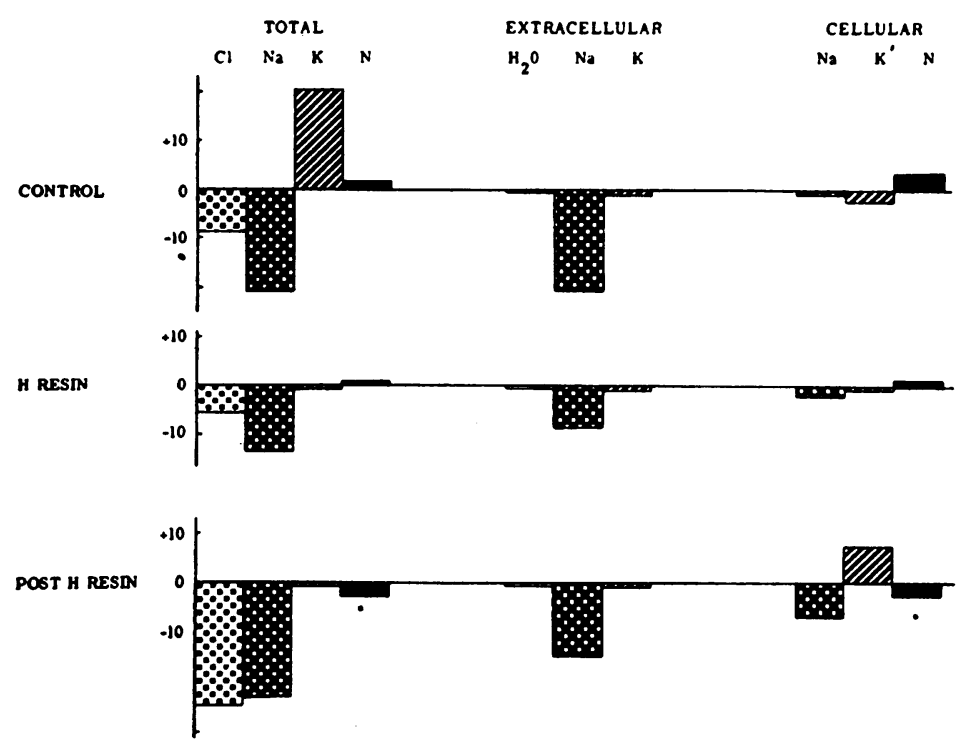

Fig. 3. External ("Total") Balances of Electrolytes and of Nitrogen Partitioned into Extracellular and Cellular Components

The graph presents the mean values during control, resin, and post resin periods. The asterisk indicates that, compared to the controls, statistically significant differences were present only in the external and cell balances of nitrogen during the post resin periods. It is obvious that on sodium restriction alone in the control periods the patients continued to lose sodium, chloride, and extracellular water throughout at essentially the same rate, as indicated by changes in the chloride space. In the control periods considerable amounts of ingested potassium were retained. This element entered cells with nitrogen since the overall cellular balance of $\mathrm{K}$ was positive but $\mathrm{K}^{\prime}$, which refers to transfers of potassium in excess of metabolism of protein, was negative. However, the scatter of values in this and in the subsequent periods resulted in considerable overlap and the "p" value was not within the limits set for statistical significance.

marily a manifestation of the remarkably reduced concentrations of serum albumin (Table I) present before, during, and after resin administration. Taking serum potassium values above 5 meq./1. as suggestive of potassium retention secondary to renal insufficiency, the data on $\mathrm{BF}, \mathrm{KM}$ and $\mathrm{DY}$ indicate the ability of the resin to lower the serum and extracellular fluid concentrations of potassium. This same effect resulted in hypokaliemia in DW.

The serial studies of erythrocyte and leucocyte counts, urine protein output, urine specific gravity, or of phenolsulphonethalein excretion did not reveal any untoward effects induced by the resin therapy. As a matter of fact the trend was toward improvement. The end result in this group to date consists of one death (DW) and three remissions, four to six months in length; obviously the survivals cannot be ascribed to resin therapy.

\section{DISCUSSION}

A practical aspect of resin therapy in nephrotic children deserves first comment. Our subjects experienced considerable difficulty in ingesting and retaining the desired amounts of the cation exchanger. Various vehicles were tried with negligible success; capsules proved to be in general more acceptable. Other essentially healthy children on the same ward on a similar regimen at the same time took the prescribed amounts of resin with only minimal objections. It should be pointed out that in general, patients on an unrestricted diet tolerated the resin much better and took larger amounts than those on the milk formula. Irrespective of whichever reasonable explanation is advanced for this difference its reality and therapeutic importance, at least in this small group of patients, cannot be denied. 
Though it is true that resin therapy superimposed on this regimen produced certain distinct changes, none of them exerted any dramatically beneficial effect. The patients did not lose sodium, extracellular water, or body weight at any faster rate. Furthermore, the post resin anorexia and voluntarily lowered milk intakes with negative nitrogen balances were probably related to resin treatment. These findings by no means exclude the possibility that resin can be useful in the treatment of edema states. They merely indicate that if essentially complete sodium restriction is achieved, this resin in the amounts herein taken apparently cannot exert any additive effect. On the other hand it is only fair to state that perhaps the resin through its acidifying effects permitted the continuation of diureses which might have otherwise ceased. It is evident, however, that even though endogenous sodium cannot be removed in significant quantities by resin in these amounts during almost complete sodium restriction, the exchanger certainly did increase stool losses of sodium during a diet which contained ample amounts of this cation. Whether or not these increments prove to be of sufficient magnitude to influence the net external balances of the ion and thereby prevent or correct edema will obviously in great measure depend on the concomitant urinary excretion of sodium.

The potassium data in these studies do suggest that this exchanger, properly used, will deviate exogenous and endogenous potassium to stools. This effect will obviously tend to forestall and to correct potassium intoxication, and its recognized threat to survival, in patients with renal diseases (24-27).

It may be of interest at this point to speculate upon various possibilities whereby the efficiency of these resins could be increased. The difficulties of ingesting sufficiently large amounts might then be resolved, although we have been able to increase, subsequent to the studies described in this paper, the intake of the exchanger by suspending it in flavored cornstarch. The size of the individual resin particles may also be important in determining the clinical efficiency of the resin. Moreover, the influence of certain dietary constituents such as potassium, calcium, and fats upon the ability of the exchange agent to increase stool so- dium excretion has not been explored. It may be, for example, that low potassium diets during ingestion of the carboxylic exchanger would permit the removal of significantly greater amounts of sodium. However, against this possibility is the observation that the sulfonic resins removed chiefly potassium in rats maintained on diets completely free of electrolytes (27).

\section{SUM M ARY}

1. On an essentially sodium-free regimen, providing ample calories, nitrogen, and potassium, a carboxylic cation exchanger in the hydrogen cycle, up to $40 \mathrm{~g}$./day, did not further increase significantly the stool losses of sodium nor accelerate the loss of edema and of body weight in nephrotic children. This therapy may have, however, prolonged the diuresis through its acidifying effects.

2. On a diet which contained considerable amounts of sodium the exchanger raised the stool sodium, thereby indicating the value of this agent in augmenting the excretion of ingested sodium.

3. The resin did increase significantly the loss of potassium via the gastrointestinal tract, but effects of this on the external balances of potassium were in great measure cancelled by a simultaneous reduction in the urinary excretion of the electrolyte. Nonetheless, serial serum potassium studies indicate the resin cancelled trends to hyperkaliemia.

\section{REFERENCES}

1. Janeway, C. A., Gibson, S. T., Woodruff, L. H., Heyl, J. T., Bailey, O. T., and Newhouser, L. R., Chemical, clinical and immunological studies on the products of plasma fractionation. VII. Concentrated human serum albumin. J. Clin. Invest., 1944, 23, 465.

2. Armstrong, S. H., Jr., Mechanisms of action of serum albumin therapy in internal medicine. Am. J. Med., $1948,4,390$.

3. Luetscher, J. A., Jr., Hall, A. D., and Kremer, V. L., Treatment of nephrosis with concentrated human serum albumin. II. Effects on renal function and on excretion of water and electrolytes. J. Clin. Invest., $1950,29,896$.

4. Hecht, G., and Weese, H., Periston, Ein neuer Blutflüssigkeitsersatz. Munchen. . med. Wchnschr., 1943, 90, 11.

5. Bohmansson, G., Rosenkvist, H., Thorsen, G., and Wilander, O., Clinical experiences with dextran as a plasma substitute. Acta chir. Scandinav., 1946, 94, 159. 
6. Bull, J. P., Ricketts, C., Squire, J. R., Maycock, W. d'A., Spooner, S. J. L., Mollison, P. L., and Paterson, J. C. S., Dextran as a plasma substitute. Lancet, 1949, 1, 134.

7. Lundy, J. S., Gray, H. K., and Craig, W. McK., Dextran in supportive therapy, with comments on periston and gelatin. Arch. Surg., 1950, 61, 55.

8. Fox, C. L., Jr., and McCune, D. J., Electrolyte changes in nephrosis; occurrence of diuresis following administration of sodium and potassium salts. Am. J. M. Sc., 1948, 216, 1.

9. Corson, S. A., O'Leary, E., Spellman, M. W., Siegel, A. L., and Harrison, E., Diuretic effects of sodium salts of organic acids in patients with cardiac and nephrotic edema. Federation Proc., 1950, 9, 25.

10. Tarail, R., Seldin, D. W., and Goodyer, A. V. N., Effects of injections of hypertonic glucose on metabolism of electrolytes in edematous patients. J. Clin. Invest., 1950, 29, 848.

11. Chasis, H., Goldring, W., and Baldwin, D. S., The effect of nitrogen mustard on renal manifestations of human glomerulonephritis. J. Clin. Invest., 1950, 29, 804.

12. Janeway, C. A., Moll, G. H., Armstrong, S. H., Jr., Wallace, W. M., Hallman, N., and Barness, L. A., Diuresis in children with nephrosis. Comparison of response to injection of normal human serum albumin and to infection, particularly measles. $\mathrm{Tr}$. A. Am. Physicians, 1948, 61, 108.

13. Meizlik, E. H., and Carpenter, A. M., Beneficial effect of measles on nephrosis; report of 3 cases. Am. J. Dis. Child., 1948, 76, 83.

14. Farnsworth, E. B., Metabolic changes associated with administration of adrenocorticotropin in the nephrotic syndrome. Proc. Soc. Exper. Biol. \& Med., $1950,74,60$.

15. Luetscher, J. A., Jr., Deming, Q. B., Harvey, J., Lew, W., and Poo, L. J., Treatment of nephrosis with cortisone. J. Clin. Invest., 1950, 29, 1576.

16. Janeway, C. A., Moll, G. H., Hallman, N., Barness, L. A., and Metcoff, J., Management of the nephrotic syndrome in children. Bull. New England Med. Center, 1949, 11, 5.

17. Dock, W., Sodium depletion as a therapeutic procedure: the value of ion exchange resins in withdrawing sodium from the body. Tr. A. Am. Physicians, 1946, 59, 282.

18. Irwin, L., Berger, E. Y., Rosenberg, B., and Jackenthal, R., The effect of a cation exchange resin on electrolyte balance and its use in edematous states. J. Clin. Invest., 1949, 28, 1403.

19. Hay, S. H., and Wood, J. E., Jr., Cation exchange resins in the treatment of congestive heart failure. Ann. Int. Med., 1950, 33, 1139.

20. Greenman, L., Peters, J. H., Mateer, F. M., Weigand, F. A., Wilkins, D., Tarail, R., Rhodes, G., and Danowski T. S., Biochemical changes accompanying the ingestion of a carboxylic cation exchanger in the hydrogen, ammonium, sodium, potassium, or calcium form. J. Clin. Invest., 1951, 30, 995.

21. Danowski, T. S., Greenman, L., Mateer, F. M., Parsons, W. B., Weigand, F. A., Mermelstein, H., and Peters, J. H., Carboxylic cation exchange resin effects in dogs. J. Clin. Invest., 1951, 30, 984.

22. Danowski, T. S., Austin, A. C., Gow, R. C., Mateer, F. M., Weigand, F. A., Peters, J. H., and Greenman, L., Electrolyte and nitrogen balance studies in infants following cessation of vomiting. Pediatrics, 1950, $5,57$.

23. Elkinton, J. R., Winkler, A. W., and Danowski, T. S., Transfers of cell sodium and potassium in experimental and clinical conditions. J. Clin. Invest., 1948, 27, 74.

24. Finch, C. A., Sawyer, C. G., and Flynn, J. M., Clinical syndrome of potassium intoxication. Am. J. Med., 1946, 1, 337.

25. Elkinton, J. R., Tarail, R., and Peters, J. P., Transfers of potassium in renal insufficiency. J. Clin. Invest., 1949, 28, 378.

26. Elkinton, J. R., Clark, J. K., Squires, R. D., Bluemle, L. W., Jr., and Crosley, A. P., Jr., Treatment of potassium retention in anuria with cation exchange resin. Am. J. M. Sc., 1950, 220, 547.

27. Ch'en, J. S., and Freeman, S., The removal of cations from solutions and the rat's alimentary canal by H form resins. J. Lab. \& Clin. Med., 1950, 35, 99.

\section{CASE REPORTS}

$D W$ - (CH 4071) - This seven year old white boy was readmitted to Children's Hospital from a convalescent home on 1/23/50 for treatment of persistent edema.

Four years earlier he had become edematous one month after an acute infection. Plasma and blood transfusions had been given without relief. In 1948 there was anasarca, blood pressure 120/62, $4+$ albuminuria, serum cholesterol $1216 \mathrm{mgm}$. \%, total protein $3.8 \mathrm{~g} . \%$, albumin $0.2 \mathrm{~g} . \%$ and globulin 3.6 g. \%. Fever and respiratory embarrassment had developed which required oxygen, antibiotic therapy and digitalization. Edema was fairly well controlled with ammonium chloride and mercurial diuretics and the patient was sent to a convalescent home. In November 1948 a diet consisting solely of sodium-free dialyzed milk was begun with improvement in clinical condition and subsidence of edema. This regime continued aside from occasional dietary indiscretion.

On admission $1 / 23 / 50$ there were marked pallor, slight generalized edema, and a soft apical systolic murmur and a BP of 100/65. His hemoglobin was $5.9 \mathrm{~g} . \%, \mathrm{RBC} 2.9$ million, and WBC 12.7 thousand and his urine contained $2+$ to $4+$ albumin, granular casts, and occasional red and white blood cells. The cholesterol was $1846 \mathrm{mgm}$. \%; other blood and serum values during his hospitalization are shown in Table I.

The sodium-free milk diet supplemented with vitamins and iron was continued with addition of hydrogen cycle 
resin. He accepted an average of only $9 \mathrm{~g}$. of the resin per day for a week. At this time an upper respiratory infection developed, with subsequent nausea, vomiting and acidosis. Improvement occurred during therapy with antibiotics, oxygen, blood transfusion, intravenous calcium gluconate and bicarbonate. On the 20th day tetany developed and was relieved by calcium therapy. This recurred on the 31 st and 62 nd hospital days. On 4/5/50 he developed congestive heart failure and became irrational; venous pressure rose, and blood pressure fell. Digitalization, oxygen, and supportive therapy were ineffective and the patient died on $4 / 6 / 50$.

At autopsy, nephrosis, right pleural effusion, ascites, dilatation of right auricle and ventricle, primary atypical pneumonia of unknown origin, congestion of liver and accessory spleen were found.

$D Y$ - $(\mathrm{CH}$ C817)-This 11 year old Chinese American boy was first admitted 9/6/49 with anasarca, albuminuria, hypercholesterolemia, and hypo-albuminemia. PSP excretion was $60 \%$ in two hours. On a low-sodium milk, rice and fruit diet, supplemented with vitamins and iron, edema subsided and the patient was discharged from the hospital. Edema recurred, but after hospitalization and sodium restriction, diuresis occurred and he was sent to a convalescent home.

On 2/18/50 the patient was readmitted with slight facial edema and abdominal fullness, but no peripheral edema. Laboratory findings were essentially unchanged, except that the hemoglobin had fallen to $7.8 \mathrm{~g}$. and the red count to 3.9. Blood and serum clinical data for his entire hospitalization appear in Table I.

Therapy consisted of low-sodium milk diet plus various combinations of cation exchange resins. On the ninth day, $14 \mathrm{~g}$. of hydrogen cycle resin were given and continued for a period of six days. After a six day control period $120 \mathrm{ml}$. of $40 \%$ urea solution were ingested daily for three days. Hydrogen cycle resin was repeated for five days, and milk protein supplement, $60 \mathrm{~g}$./day, was added to the diet. However, the clinical condition of the patient remained unchanged. During this time protein intake was $90 \mathrm{~g}$. daily, with urinary losses of 10-13 g./day. Unexplained abdominal pain and temperature elevations present from the 32 nd to the 35 th day were treated with penicillin.

On the 66th day he was placed on a general diet with $\mathbf{4 0}$ g. of the hydrogen cycle resin daily. There was disappearance of edema and weight loss of $2 \mathrm{Kg}$. with subjective and objective improvement.

Subsequently resin therapy was repeated from the 110th to the 117th day. No significant change appeared in urine or blood throughout therapy.

$B F-(\mathrm{CH} 0801)$ - This six year old negro boy was readmitted $3 / 6 / 50$ with edema, marked ascites and $3+$ albuminuria.

One month earlier he had been admitted with periorbital and pretibial edema, vomiting, abdominal cramps, mild diarrhea, and enlargement of the abdomen of three days' duration. BP was 102/64. There was $3+$ to $4+$ albuminuria and a few white and red blood cells in the urine.
The NPN was $32 \mathrm{mgm}$. \%, total protein $4.3 \mathrm{~g}$. \% with $0.7 \mathrm{~g}$. albumin. Cholesterol was $864 \mathrm{mgm}$. \%. The intravenous pyelogram was normal. A diagnosis of nephrosis was made and a low-salt high-protein diet given with improvement. He was discharged $2 / 24 / 50$.

He was readmitted on $3 / 6 / 50$ with edema, marked ascites, and $3+$ albuminuria. Blood and serum analyses appear in Table I. Hemoglobin was 10.5, RBC 3.6, WBC 7.8 thousand. On a diet consisting exclusively of a lowsodium milk formula the edema diminished rapidly during the first 12 days. From the 12th to the 18th days the patient received hydrogen cycle cation exchange resin. During this time no change in his condition was noted.

Dialyzed milk formula was continued until the 20th hospital day when intake was changed to low-salt diet and hydrogen cycle resin was again given. This regimen was associated with rapid accumulation of edema fluid until it was interrupted on the 34th day by an acute episode of fever, vomiting and severe abdominal distention and pain suggestive of peritonitis. Recovery from this acute episode occurred after four days of antibiotic therapy. On a low-sodium milk formula, diuresis and disappearance of edema occurred rapidly. There was no change in albuminuria.

The child remained on this diet and almost completely free of edema until 6/12/50, when a general diet and $20 \mathrm{~g}$. each of hydrogen and potassium cycle resins were given. Within one week edema appeared in severe degree. A lowsodium milk diet with rice, fruit, and "salt-free" bread was administered for the remainder of his hospital stay. Hydrogen form resin was resumed, and in eight days edema subsided and a weight loss of $1 \mathrm{Kg}$. occurred. Albuminuria persisted throughout the study.

$K M$ - (CH M6990) - This two year old white girl was admitted $5 / 6 / 50$ because of persistent edema despite dialyzed milk and salt-free cereal diet.

Two years before there had been swelling of the face, legs, and abdomen of two weeks' duration subsequent to an upper respiratory infection. On admission in 1948 the child was pale, poorly developed, with periorbital and peripheral edema. BP was $120 / 75$. There was $4+$ albuminuria, $6 \mathrm{RBC} / \mathrm{hpf}$, specific gravity 1.037. A normochromic anemia and leucocytosis were present. Blood NPN was $30 \mathrm{mgm}$.\%, serum cholesterol $608 \mathrm{mgm}$. \%, albumin 0.4 and globulin $3.7 \mathrm{~g}$. \%. Diuretic therapy produced slight improvement.

On 5/6/50 there were generalized edema and hepatomegaly, blood pressure was $105 / 75$, albumin $3+$ to $4+$, and a few red cells and granular casts were present in the urine. Hemoglobin was 7.5 g. \%, RBC 3.2, and WBC 9.1. Excretion of PSP was $50 \%$ in two hours.

The patient was fed only low-sodium milk supplemented with vitamins and iron. After one week a slight reduction in facial edema was noted, with weight decrease of 0.8 $\mathrm{Kg}$. Hydrogen cycle resin was then given for a period of 15 days. This was poorly accepted by the patient, only small amounts being taken. During administration of resin there was no change in blood or urine findings. Serum values appear in Table $I$. 